\title{
How are Western water districts managing groundwater basins?
}

\begin{abstract}
A study of 18 districts finds that common groundwater management approaches that minimize economic impacts to agricultural users include low-cost monitoring and a flexible combination of supply augmentation and demand management.
\end{abstract}

by Claire Newman, Richard Howitt and Duncan MacEwan

\section{Abstract}

Making the transition from open-access groundwater rights to sustainable groundwater management is a formidable task for newly formed groundwater sustainability agencies in California. As agencies begin to decide how to make equitable water allocations, how to monitor groundwater use and what mix of supply- and demand-side mechanisms to adopt to satisfy sustainability criteria, the groundwater management strategies in place across other basins in the western United States are worth studying. We surveyed 18 groundwater districts in California and other Western states to identify the management approaches and practices they have instituted. The conclusions we draw suggest a correlative rights framework of water allocation with phase-ins for heavy users; metered pumping; flexible arrangements for trading and carrying over allocations for multiple years; and incentivizing groundwater recharge, including recharge from deep percolation from crops. Rigid formulas for significantly reducing groundwater use in medium- and high-priority basins are likely to have significant negative effects on the regional economy.

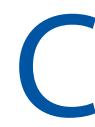
alifornia’s Sustainable Groundwater Management Act of 2014 (SGMA) overhauls groundwater management in California. Currently, most California groundwater basins are unmanaged and extractions from basins are unmeasured. SGMA requires the formation of local groundwater agencies (GSAs) to provide management (DWR 2016a) for all basins designed by the state as medium- or highpriority. The GSAs have the unenviable task of unifying and managing a set of water users, many of whom have different objectives. The law also requires medium- and high-priority groundwater basins in a state of critical overdraft to adopt a groundwater sustainability plan (GSP) by Jan. 31, 2020, and medium- and high-priority basins not in a state of critical overdraft to adopt GSPs by Jan. 31, 2022 .

If GSAs fail to meet these deadlines (or a GSA has not been formed), the law has provisions to designate a basin as probationary and subject to regulation by

Online: https://doi.org/10.3733/ca.2018a0004
An engineering geologist with the California Department of Water Resources measures the water depth at an agricultural well in Colusa County. Periodic measurements at wells around the state feed into databases that track changes in groundwater levels.
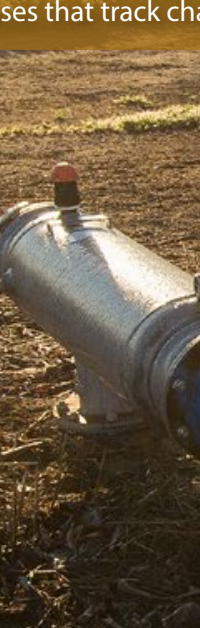

28 GALIFORNIA AGRICULTURE E 
the State Water Resources Control Board (SWRCB). Successfully navigating the complicated regulatory process will require GSAs to balance demands across water users with different preferences and water values. With tight deadlines, often competing interests among different water users, and strict sustainability requirements, GSAs face a difficult transition.

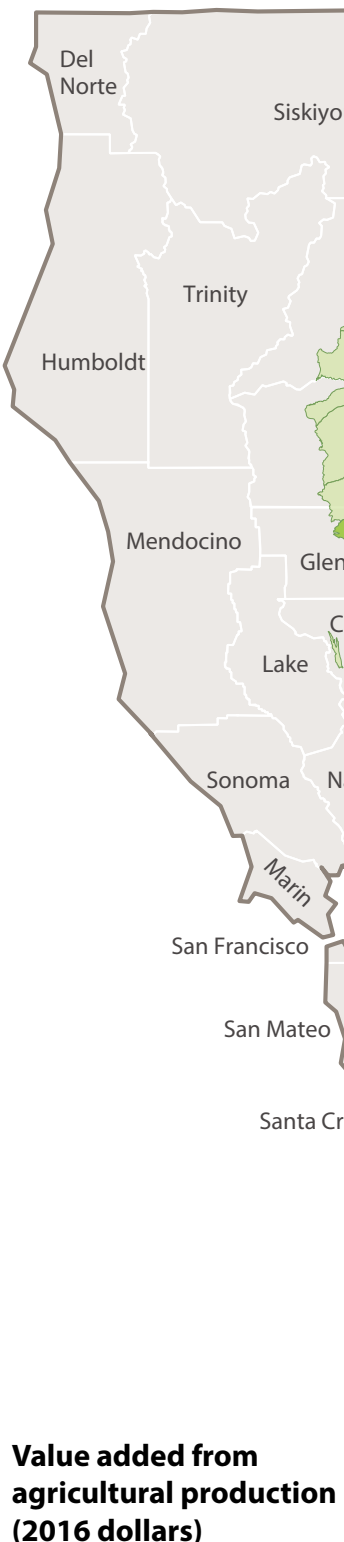
(2016 dollars)

$\$ 0-\$ 250$ million

$\$ 250-\$ 500$ million

$\$ 500-\$ 1,000$ million

$\$ 1,000-\$ 1,500$ million

$\$ 1,500-\$ 1,750$ million

Bulletin 118 high-priority or medium-priority basins in the Central Valley

FIG. 1. Value added to local economies by agricultural production in the medium- and high-priority groundwater basins in the Central Valley. of groundwater sub-basins. Currently, 127 of the 515 sub-basins in the state are classified as medium- or high-priority (DWR 2016b). As of January 8, 2018, 266 unique local agencies have formed GSAs that account for 378 areas (GSAs may encompass more than one sub-basin, and there may be multiple GSAs within a sub-basin). Figure 1 illustrates the boundaries of the 43 medium- and high-priority groundwater basins in the Central Valley as defined by Department of Water Resources Bulletin 118.

Moving forward, GSAs must work to adopt GSPs that are acceptable to the parties they represent and that result in demonstrable progress toward sustainable management. Specifically, GSPs must avoid the six sins of groundwater overdraft, defined by SGMA as the "significant and unreasonable" lowering of groundwater elevations, reduction in groundwater storage, salt water intrusion, water quality degradation, land subsidence and negative effects on beneficial uses of interconnected surface water.

California has implemented groundwater management in a few basins under AB 3030 plans and SB 1938; however, under these bills there is no statewide mandate to implement management as there is under SGMA. Since groundwater management is a new process in nearly every basin, it seemed useful to identify what has worked elsewhere and why.

\section{Survey of 18 water districts}

We surveyed 18 districts in the western United States that have already implemented sustainable groundwater management to compare their practices, identify commonalities and highlight themes in the survey responses. The districts selected were in California, as far north as Washington and as far east as Kansas and Texas

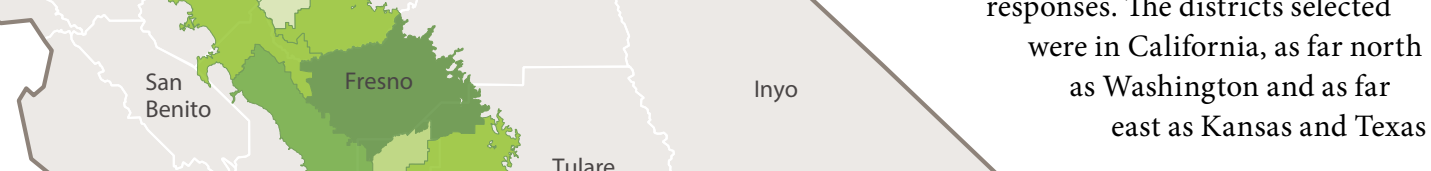




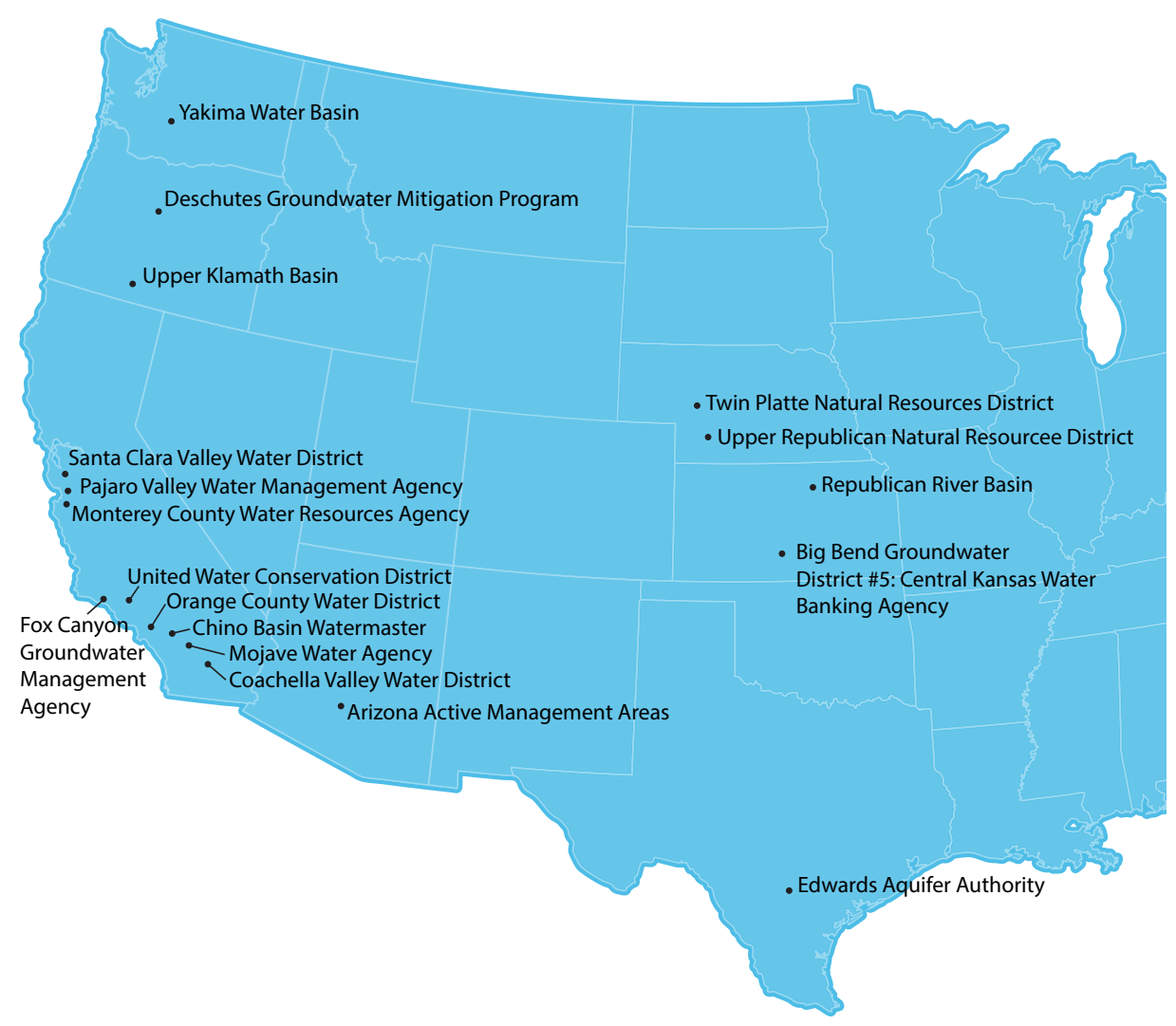

FIG. 2. Locations of the 18 surveyed water districts.

TABLE 1. Characteristics and current practices of the 18 surveyed water districts

\begin{tabular}{|c|c|c|c|c|c|}
\hline Water district & $\begin{array}{l}\text { Groundwater } \\
\text { rights }\end{array}$ & Metering & Fee structure & $\begin{array}{l}\text { Trading } \\
\text { permitted }\end{array}$ & $\begin{array}{l}\text { Carryover } \\
\text { permitted }\end{array}$ \\
\hline Arizona Active Management Areas & Beneficial use & Varies & Varies by AMA & Yes & No \\
\hline $\begin{array}{l}\text { Big Bend Groundwater District \#5: Central Kansas } \\
\text { Water Banking Agency }\end{array}$ & Appropriation & Annual & Land and water assessment & Yes & Yes \\
\hline Coachella Valley Water District & Beneficial use & Annual & Assessment surcharge & No & No \\
\hline Deschutes Groundwater Mitigation Program & Appropriation & Annual & Mitigation costs & Yes & No \\
\hline Edwards Aquifer Authority & Appropriation & Annual & User type fees & Yes & No \\
\hline Fox Canyon Groundwater Management Agency & $\begin{array}{l}\text { Irrigation } \\
\text { allowance }\end{array}$ & Semiannual & $\begin{array}{l}\text { Extraction and overallocation } \\
\text { surcharge }\end{array}$ & No & Yes \\
\hline Mojave Water Agency & Adjudicated & Quarterly & Overallocation fee & Yes & No \\
\hline Monterey County Water Resources Agency & Beneficial use & Annual & $\mathrm{N} / \mathrm{A}$ & No & No \\
\hline Orange County Water District & Beneficial use & Monthly & Overallocation surcharge & No & No \\
\hline Pajaro Valley Water Management Agency & Beneficial use & Annual & Varies by zone & No & No \\
\hline Republican River Basin & Appropriation & Annual & Varies by district & Yes & Yes \\
\hline Santa Clara Valley Water District & Beneficial use & Varies & Varies by zone & No & No \\
\hline Twin Platte Natural Resources District & Appropriation & Annual & Per acre & Yes & Yes \\
\hline United Water Conservation District & Beneficial use & Semiannual & Varies by zone & No & No \\
\hline Upper Klamath Basin & Adjudicated & Annual & Per acre & No & No \\
\hline Upper Republican Natural Resources District & Allocation per acre & Semiannual & $\mathrm{N} / \mathrm{A}$ & Yes & Yes \\
\hline Yakima Water Basin & Beneficial use & Annual & Per acre & No & No \\
\hline
\end{tabular}

Source: Primary survey by ERA Economics LLC. (fig. 2). Table 1 shows the relevant characteristics of the 18 districts.

We interviewed district managers and reviewed groundwater management plans, agricultural water management plans and other district documents. We focused on five themes that we think are central to the operation of GSPs: (1) allocating the sustainable yield of the basin, (2) measuring and monitoring individual pumping, (3) setting the level and type of management fees charged, (4) setting the degree to which intertemporal and interspatial trading of pumping rights is permitted and (5) designing incentives to improve both distributed and concentrated recharge.

\section{Allocating basin sustainable yield}

The first important component of effective groundwater management is allocating the sustainable yield of the basin. This involves three tasks: (1) defining the sustainable yield and how it relates to the safe yield of the basin, (2) quantifying the basin sustainable yield and (3) allocating the sustainable yield across groundwater users.

\section{Definition of sustainable yield}

Before defining a basin's sustainable yield, we need to distinguish the subtle difference between sustainable and safe yield of a basin. The basin safe yield balances extraction with all sources of recharge; it's a simple measure of quantities. The basin sustainable yield is 
defined in terms of the SGMA legislation (and corresponding regulations) as a yield from the basin that does not impose long-term economic or environmental costs to overlying basin residents. It may consider the rate of groundwater extraction, for example, if it might result in land subsidence or reductions of hydrologically associated stream flows or vernal pools. Both safe and sustainable yields are usually measured as the average over a 5- to 10 -year period. In some situations, sustainable and safe yields will be the same, but in others sustainable yield will be lower than safe yield. All the 18 districts surveyed needed to define and allocate the basin sustainable yield.

Defining the sustainable yield of a basin is a hydrologic question that requires agreement on a water balance accounting based on a groundwater model that is accepted by a majority of a district's stakeholders. For example, in the Chino Basin the water balance is quantified by using a calibrated model of developed yield (net inflow into the basin) over 50 years that incorporates the Santa Ana River Underflow New Yield (SARUNY) to determine the net recharge to the basin (Wildermuth Environmental 2013). The groundwater model is used to make projections of currently developed yield and the future sustainable yield through production and replenishment based on expected hydrology. Getting all parties to agree to the water balance accounting is essential. In many basins in California, such as those in Kern County, which covers a large area and has multiple GSAs, achieving consensus will be a difficult task.

Sustainable yield can be defined for a single objective (e.g., to limit groundwater extraction) or for multiple objectives (e.g., to limit groundwater extraction, prevent saline water intrusion into the aquifer and maintain river flows, vernal pools or wetlands). For basins with multiple objectives and complicated hydrologic linkages between the environmental and economic components of groundwater management, the optimal rate of groundwater extraction is often dominated by environmental constraints; and more nuanced pumping rules are usually required, varying by time and location. For example, management of the basin in the Upper Republican Natural Resources District in Nebraska requires surveys of aquifer levels, water flows and interbasin transfers and conserving wildlife habitats across streams, reservoirs and wetlands.

Most of the critically overdrafted basins in California have deep groundwater tables, typically several hundred feet below the surface. Essentially this decouples the groundwater level from environmental outcomes (e.g., surface waters), except for subsidence. For basins without subsidence and environmental concerns, optimal groundwater management simplifies into an economic decision of the optimal depth at which to stabilize the aquifer. In these cases, the management usually requires matching the average pumping to the sustainable yield of the basin, which is approximately equal to the safe yield.

\section{Quantification of sustainable yield}

Quantification of a basin's sustainable yield is usually an iterative process over time. Nine of the 18 basin management agencies surveyed for this study have mechanisms for adjusting the sustainable yield. For example, the Chino Basin Watermaster reevaluates sustainable yield annually. The sustainable yield of a basin cannot be a static value because it is influenced by the recharge that is, in turn, changed by the overlying irrigated acreage, the crops grown and the irrigation technology. If water district managers are required to manage groundwater basins by reducing irrigation on the overlying land, the quantity of recharge from deep percolation will also be reduced, and thus the sustainable yield of the basin will decrease. That is, even without factoring in the effects of climate change, the sustainable yield of a basin is a moving target that must be adjusted over time. It follows that management rules should be designed to be equitable - and perceived as such - but also be subject to tuning as managers see how the biophysical system evolves.

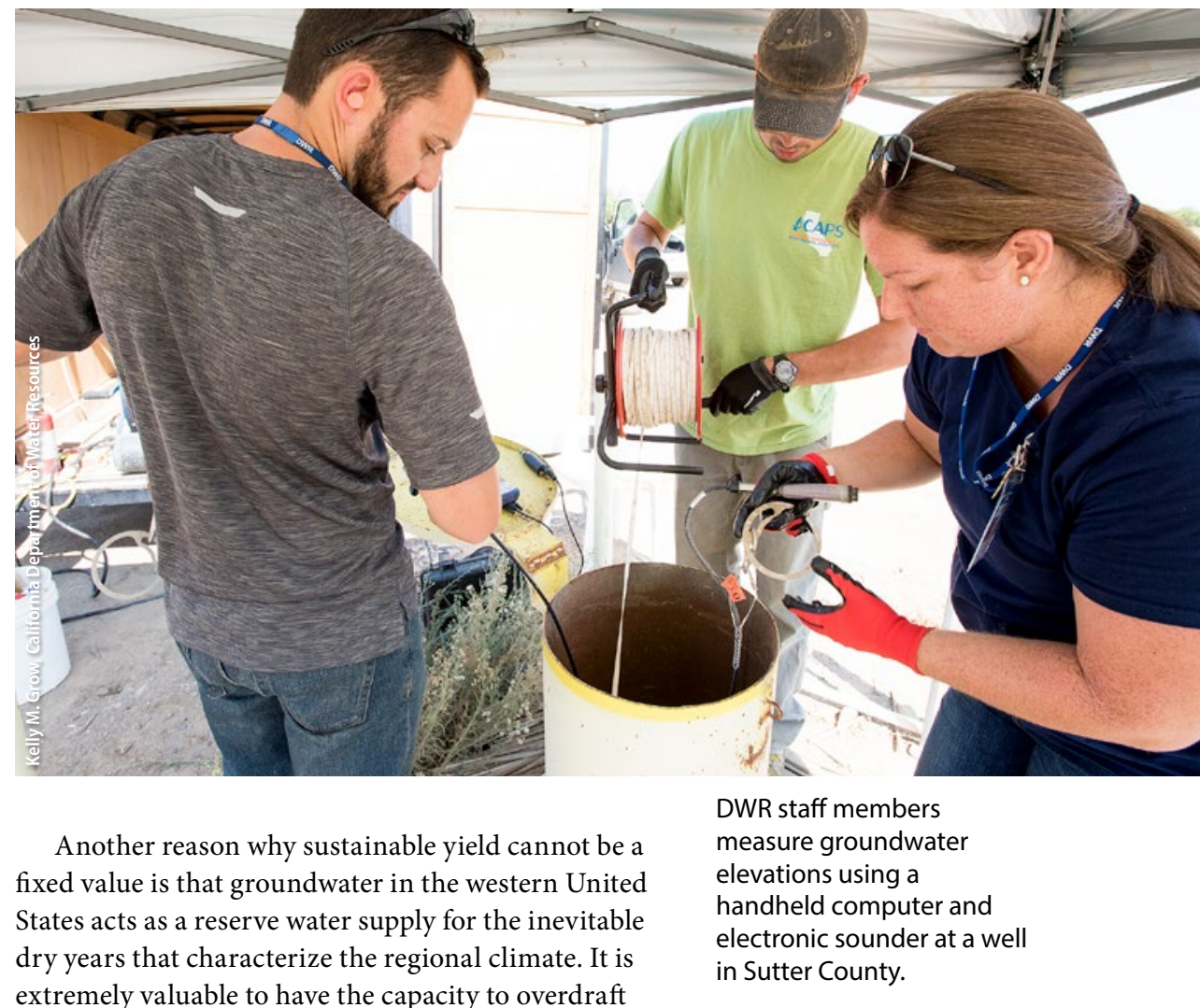
extremely valuable to have the capacity to overdraft groundwater during dry years. However, overusing groundwater in this way can lead to reduced pumping or an increased need for recharge in years with aboveaverage rainfall. Effective management strategies allow for this trade-off over time, and for the sustainable yield of a basin to change over time.

\section{Allocation of sustainable yield}

Groundwater property rights affect the allocation of the basin sustainable yield. Our survey shows that 
Drilling for groundwater in Yuba County. The authors' survey results suggest that a correlative rights approach, which assigns water shares by overlying land area, is the most equitable approach to allocate groundwater. eight of the 18 districts have groundwater rights based on beneficial use, five have appropriative groundwater rights, three are adjudicated and two use a per-irrigated acre allocation rule. The more complex allocation rules are found in parts of Nebraska and Colorado where the linkage of groundwater pumping to river flows must be clearly defined so that river flow standards are met over different water year types and locations. For example, on Colorado's Front Range, groundwater pumping linked to river flows is constrained by a time-varying criterion known as the run of the river.

Some basins have already defined extraction allocations in the form of adjudicated pumping quotas and pumping rules. If these allocations are not consistent with the sustainable yield standard established by SGMA, they will need to be modified accordingly. For basins with rights based on prior allocation, reductions in pumping to meet the sustainable yield are based on seniority of rights. However, this raises the question of whether prior appropriators have an absolute priority whereby adjustment costs to meet sustainable yield are inflicted on the lowest-priority pumpers first. An alternative method is to view the adjustments of groundwater appropriations as changes in shares of the sustainable yield, and assign the reduced pumping yield in proportion to the priority level so that the burden of adjustment is shared in proportion to the established priority levels.

Most of California's groundwater basin extractions are defined by the correlative

rights doctrine, which allocates groundwater in proportion to the overlying land area regardless of prior use. For the surveyed basins that have groundwater pumping defined by beneficial use, groundwater rights are similar to correlative rights. Adaptation to a limited sustainable yield from the basin based on correlative rights seems to be the most equitable allocation in the long run. However, the allocation of correlative rights in California is complicated by those groundwater users who are extracting substantially more on average than their share of the basin sustainable yield, for example, agricultural users with recently developed permanent crop plantings that have inflexible water needs, and cities that rely on groundwater.

Given the per-acre water requirements of urban development in the Central Valley, cities are likely extracting more than their share of the sustainable yield based on the urban land area. Furthermore, they have often gone beyond their boundaries to seek groundwater extraction sites. Since cities do not have the same flexibility for use changes as agriculture, fair-share negotiations will be tense, with cities probably claiming a higher beneficial use and health and safety concerns for their extraction patterns. A rigid application of correlative rights under SGMA to cities and current over-appropriators is likely to invite strong opposition and excessive adjustment costs to some parties. These pumpers should be managed by a phase-in period under which their short-run grandfathered excess pumping allowances and long-run extraction quantities are clearly defined.

\section{Monitoring groundwater extraction}

The strongest common theme running through the survey is that every basin management district monitors groundwater pumping. The adage that you cannot manage what you cannot measure seems to hold true for groundwater management. Two methods of measuring extractions dominated the survey responses. Districts either use well meters or they estimate groundwater use based on the standard applied water requirements for crops grown in the region. Meters provide the best accuracy, and offer the possibility of wireless reporting, but the devices and installation are costly and direct metering can raise privacy objections from landowners. Crop-based groundwater 
use estimates by zone, such as used in the Santa Clara basin, are less accurate and remove any incentives for improved water use technology. Groundwater use estimates based on aggregate basin measures are even less precise than those based on zones.

The frequency of monitoring reported from the surveyed districts varied over a range from annual, semiannual, quarterly and monthly. The decision on how frequently to monitor pumping is driven by the costs of using imprecise data. In Orange County, where saline intrusion is controlled by maintaining a freshwater mound, the cost of monthly monitoring is justified. The same precise monitoring would be required in basins where domestic water supplies, subsidence or linked river flows are of concern. In basins with low lateral conductivity rates, annual monitoring is sufficient.

Direct monitoring of groundwater extraction is potentially contentious. During the debate over SGMA in the Legislature, the requirement for compulsory groundwater management was supported by several groups, such as the Association of California Water Agencies and the California Water Foundation. However, farmers were united in their opposition to it, and the legislators from rural districts urged Governor Brown to veto it (Austin 2014). In our survey, we found that, because direct monitoring is unpalatable, some basin management districts provide exemptions to agriculture.

If the monitoring stays reasonably local and pumping measurements can be aggregated before they are transmitted to oversight agencies assessing regional compliance, so they don't reveal individual performance, monitoring may be less of a concern for most users. Even with local control, the perception, correctly, is that SGMA requires a shift from individual to collective decision making. Conflict resolution programs may ease the introduction of a GSP, but pushback over voluntary and mandatory groundwater well monitoring is to be expected (Theesfeld 2011).

One emerging option to estimate groundwater use at a low cost and on a consistent basis is to use satellite data on energy spectra reflected by a crop to estimate net evapotranspiration. Combining that information with data on applied surface water, type of irrigation system, and crop, the net use of groundwater can be calculated more precisely, removing human measurement error and self-reporting issues that are common to other approaches. Another advantage of remotely sensed metering is that it avoids the high capital cost of well meters and the implicit intrusion on private land.

For example, the Fox Canyon Groundwater Management Agency includes in its annual budget consultant contracts for meter and well inspections $(\$ 100,000)$, online support services $(\$ 43,000)$ and additional equipment $(\$ 2,000)$ to maintain the monitoring of wells. Additionally, a remotely sensed system, because it is automated, cannot discriminate across farms. Clearly, a satellite is both impartial and equitable in its measurements.
In Idaho, the satellite-based Mapping Evapotranspiration at high Resolution with Internalized Calibration (METRIC) system has been widely adopted; for example, it has been used to generate monthly and seasonal evapotranspiration (ET) maps predicting irrigation flows and basin recharge for the Snake Plain Aquifer (Allen et al. 2005). It is also being increasingly used in California and other states (Allen et al. 2005). However, none of the districts surveyed use remote sensing for estimating groundwater use.

\section{Management approaches}

As GSAs formulate their GSPs, the critical action will be how to select and implement one among the many groundwater management approaches. Our survey revealed supply-side management approaches and demand-side management approaches that include water trading and fees.

\section{Supply-side mechanisms}

Managing groundwater supply is the most popular approach, probably because it appeals to our past "build first and ask questions later" engineering traditions. Supply management is a command and control approach in which growers are forced to use less groundwater, additional recharge is supplied through imports of surface water, and changes in management approaches occur, such as stress irrigation and crop switching. However, there are limits to the effectiveness of this approach: for example, importing surface water may be possible, but it is typically expensive. In practice, there are limited opportunities for additional surface storage in California, thus limiting the effectiveness of stabilizing a basin through increased supplies.

Applying water to agricultural lands outside production seasons may provide additional basin percolation (O'Geen et al. 2015). However, it remains to be seen how much additional recharge can be achieved from flooding cropland in winter (Nelson 2015), and whether this strategy will cause negative agricultural production or environmental externalities. Browne and Micretich (1988) demonstrate the link between long flood durations and the development of crown rot for apples, and a recent article by Bostock et al. (2014) explores the susceptibility of plants to diseases after abiotic stresses including extended flooding.

The key questions for supply management approaches in California are the availability of additional surface water, and whether the benefits of supply augmentation justify the costs. The value of a distributed recharge source of water under SGMA may be high enough to challenge the profitability of field crops on coarse soils, which are prime soils for effective percolation. O'Geen et al. (2015) identify those areas in the Central Valley that have soils with hydraulic conductivities of over 300 millimeters per hour. Many of them are in continuity with underlying groundwater, 


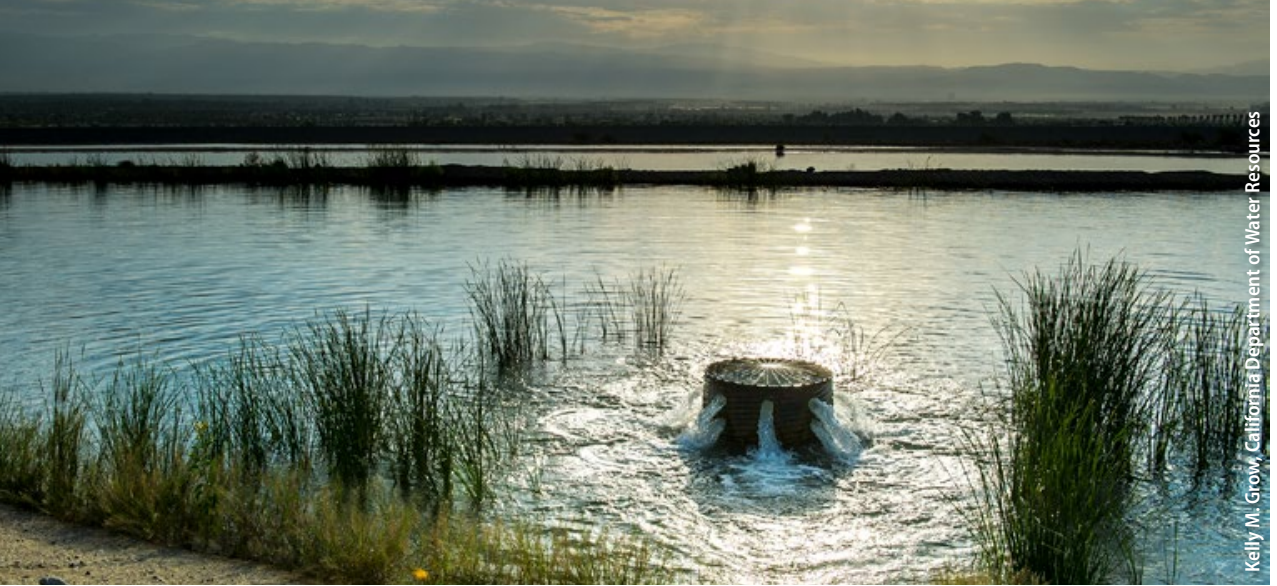

Coachella Valley Water District's Thomas E. Levy Groundwater Replenishment Facility percolates imported Colorado River water into the eastern subbasin of the Coachella Valley's aquifer, replenishing 40,000 acrefeet of water annually.

for example, the sandy-bottomed recharge basins in the Consolidated Irrigation District near Selma. The Kern Water Bank is similarly located on the alluvial fan soils of that river that were taken out of production. Of course, these high conductivity soil properties need to be combined with adequate surface supplies to result in effective and commercially viable artificial recharge systems.

\section{Demand-side mechanisms}

Demand management approaches may be a cheaper way to achieve a sustainable groundwater balance. They include water trading and other market programs and fee structures to incentivize growers to use water efficiently. Reallocating annual pumping allocations among users in the form of exchanges or trading pumping allocations within the basin takes place in seven of the 18 districts surveyed. The flexibility introduced from users being able to trade pumping allocations is particularly important during dry cycles.

Other districts, for example, the Coachella Valley Water District, charge large fees to disincentivize users from overpumping. The fees are applied not only to the amount that exceeds the entitlement, but to the entire quantity pumped for that reporting period, thus creating a significant incentive to remain within pumping allotments. Table 1 shows the very wide range of fee structures the districts use to manage groundwater. They can be summarized as flat use fees levied to offset the costs of running the district, fees based on the mitigation costs of supplementing groundwater recharge, and fees for different zones that reflect the differential impact on river flows or environmental systems.

A district may impose only fees for the administrative costs of running the district. They are substantial and can be divided into start-up and operating costs. Start-up costs fluctuate depending on administrative needs, the operation costs of the monitoring system, legal considerations, and any additional infrastructure. The operating costs for groundwater management include metering, monitoring, and establishing the annual sustainable yield.

Alternatively, fees can be used as a management tool for the mitigation of impacts, or replenishment of groundwater stocks by recharge or conservation. Eight of the 18 districts surveyed impose surcharge fees for overpumping or fees to cover replenishment costs. For California basins that are heavily overdrafted, replenishment fees to augment surface supplies or recharge groundwater aquifers will be critical.

Replenishment fees have been a successful and long-lasting management tool for the Orange County Water District. Early threats of seawater intrusion there stimulated heavy investment of these fees in water recycling systems and additional sources of surface water supplies for recharge purposes. Future management by replenishment fees is less likely in basins in the southern San Joaquin Valley. In these regions access to alternative surface water supplies to offset overdraft will be more limited in the future, given the flow modifications on the Lower San Joaquin River and its three eastside tributaries proposed by the California Water Resources Control Board (SWRCB 2012).

We anticipate that the fee structure necessary for California sustainable groundwater management will include a fixed fee for basin administration and fees for replenishment when pumping above the sustainable yield occurs. The replenishment fees will vary by year and location, but they should be consistent with California's Proposition 218 that requires that additional fees must reflect the cost of providing additional service.

Table 2 summarizes the fees levied by the 18 surveyed districts. Pajaro Valley Water Management Agency, Santa Clara Valley Water District and United Water Conservation District charge growers according to the volumetric amount of water they pump. Fox Canyon Groundwater Management Agency and other districts focus on incentivizing growers to stay within their allocation by levying minimal extraction and administration fees and expensive surcharges for exceeding allocations. The relative costs to the growers in these 18 districts are highly variable, based on district priorities, management system and enforcement policies.

\section{Economic stability, trading and carryovers}

SGMA regulations are vague in defining groundwater sustainability objectives, and what constitutes a "significant and undesirable" outcome is left largely up to the GSAs to determine. Our observation is that, so far, most water managers and experts are focusing on environmental criteria and stabilizing pumping around a historical average as the way to avoid the six sins of SGMA. An economist might convincingly argue that socioeconomic outcomes for affected parties, such as agriculture, should be factored into sustainability criteria.

\section{Groundwater and the economy}

Agriculture is a dominant share of the economy in many regions causing employment, income growth, 
and local taxes to be directly linked with the value of agricultural output. We estimate the gross value of agricultural production in each basin by combining statewide cropping data within basin boundaries and 2014 U.S. Department of Agriculture National Agricultural Statistics Service prices and yields in a basin-level economic model. We then applied a value-added multiplier from the Impacts from Planning Analysis (IMPLAN v3.1) model to identify the total value added (total change from benefits and costs) in each basin from the agriculture industry. Figure 1 shows that irrigated agriculture is a dominant share of the local economy across the medium- and high-priority Central Valley basins, generating $\$ 250$ million to $\$ 1.75$ billion of value added.

In total, agricultural production in these basins, excluding processing and manufacturing, contributes

TABLE 2. The 18 surveyed water districts, main crops, and fee structures

\begin{tabular}{|c|c|c|c|c|}
\hline District & Crops & Administrative fee & Water fee & Replenishment fee \\
\hline $\begin{array}{l}\text { Arizona Active } \\
\text { Management Areas }\end{array}$ & $\begin{array}{l}\text { Cattle, cotton, } \\
\text { vegetables }\end{array}$ & $\begin{array}{l}\text { Phoenix: } \$ 45 / A F \\
\text { Pinal: } \$ 45 / A F \\
\text { Tucson: } \$ 45 / A F\end{array}$ & $\begin{array}{l}\text { Phoenix: } \$ 294 / A F \\
\text { Pinal: } \$ 294 / A F \\
\text { Tucson: } \$ 294 / A F\end{array}$ & $\begin{array}{l}\text { Phoenix: } \$ 246 / A F \\
\text { Pinal: } \$ 225 / A F \\
\text { Tucson: } \$ 276 / A F\end{array}$ \\
\hline $\begin{array}{l}\text { Big Bend Groundwater } \\
\text { District \#5: Central Kansas } \\
\text { Water Banking Agency }\end{array}$ & Wheat, corn, cattle & $\begin{array}{l}\text { Land assessment: } \\
\$ 0.05 / \text { acre }\end{array}$ & Water assessment: $\$ 0.67 / \mathrm{AF}$ & $\mathrm{N} / \mathrm{A}$ \\
\hline Chino Basin Watermaster & $\begin{array}{l}\text { Ornamentals, } \\
\text { root vegetables, } \\
\text { bedding plants }\end{array}$ & $\begin{array}{l}\text { Appropriative: } \\
\$ 41.96 / \mathrm{AF} \\
\text { Agriculture: } \$ 22.04 / \mathrm{AF}\end{array}$ & $\begin{array}{l}\text { Appropriative: } \$ 15.59 / \mathrm{AF} \\
\text { Agriculture: } \$ 8.19 / \mathrm{AF}\end{array}$ & $\$ 519-\$ 611 / A F$ \\
\hline $\begin{array}{l}\text { Coachella Valley Water } \\
\text { District }\end{array}$ & $\begin{array}{l}\text { Grapes, bell } \\
\text { peppers, lemons }\end{array}$ & Included in water fee & Water rate: $\$ 33.48 / \mathrm{AF}$ & $\begin{array}{l}\text { West Whitewater River Subbasin: } \$ 128.8 / \mathrm{AF} \\
\text { Mission Creek Subbasin: } \$ 123.3 / \mathrm{AF} \\
\text { East Whitewater River Subbasin: } \$ 66.00 / \mathrm{AF}\end{array}$ \\
\hline $\begin{array}{l}\text { Deschutes Groundwater } \\
\text { Mitigation Program }\end{array}$ & $\begin{array}{l}\text { Potatoes, seed } \\
\text { crops, alfalfa }\end{array}$ & Water right: $\$ 280$ & $\begin{array}{l}\text { Per acre of land: } \$ 2 \\
\text { Surface water substitution: } \$ 725\end{array}$ & $\begin{array}{l}\text { Temporary mitigation credit: } \$ 70-\$ 150 / \text { acre } \\
\text { Permanent mitigation credit: } \$ 2,000: 5.000 / \text { acre }\end{array}$ \\
\hline $\begin{array}{l}\text { Edwards Aquifer } \\
\text { Authority }\end{array}$ & $\begin{array}{l}\text { Livestock, sorghum } \\
\text { wheat }\end{array}$ & Included in water fee & $\begin{array}{l}\text { Agricultural: } \$ 2 / A F \\
\text { M\&l: } \$ 36-\$ 116 / A F\end{array}$ & Overallocation surcharge: \$84/AF \\
\hline $\begin{array}{l}\text { Fox Canyon Groundwater } \\
\text { Management Agency }\end{array}$ & $\begin{array}{l}\text { Strawberries, } \\
\text { celery, raspberries }\end{array}$ & $\begin{array}{l}\text { Sustainability fee: } \\
\text { \$4/AF }\end{array}$ & $\begin{array}{l}\text { Extraction fee: } \$ 6 / A F \\
\text { Unmetered extraction fee: } \$ 12 / A F\end{array}$ & $\begin{array}{l}\text { Exceeding allocation surcharge: } \\
\text { Tier } 1: \$ 1,315 / \mathrm{AF} \\
\text { Tier } 2: \$ 1,565 / \mathrm{AF} \\
\text { Tier } 3: \$ 1,815 \mathrm{AF}\end{array}$ \\
\hline Mojave Water Agency & $\begin{array}{l}\text { Alfalfa, pasture, } \\
\text { orchards }\end{array}$ & $\mathrm{N} / \mathrm{A}$ & $\mathrm{N} / \mathrm{A}$ & Overallocation fee: $\$ 484 / A F$ \\
\hline $\begin{array}{l}\text { Monterey County Water } \\
\text { Resources Agency }\end{array}$ & $\begin{array}{l}\text { Strawberries, } \\
\text { broccoli, celery }\end{array}$ & $\begin{array}{l}\text { Administrative fee: } \\
\$ 2.23-\$ 8.98 / \text { acre }\end{array}$ & $\mathrm{N} / \mathrm{A}$ & $\mathrm{N} / \mathrm{A}$ \\
\hline $\begin{array}{l}\text { Orange County Water } \\
\text { District }\end{array}$ & $\begin{array}{l}\text { Strawberries, } \\
\text { oranges, } \\
\text { ornamentals }\end{array}$ & Included in water fee & Basin equity assessment: $\$ 80 / \mathrm{AF}$ & Overallocation fee: $\$ 322 / A F$ \\
\hline $\begin{array}{l}\text { Pajaro Valley Water } \\
\text { Management Agency }\end{array}$ & $\begin{array}{l}\text { Strawberries, } \\
\text { artichokes, broccoli }\end{array}$ & Included in water fee & $\begin{array}{l}\text { Outside delivered water zone } \\
\text { (DWZ): } \$ 203 / \mathrm{AF} \\
\text { Inside DWZ: } \$ 258 / \mathrm{AF} \\
\text { Unmetered: } \$ 184 / \mathrm{AF} \\
\text { Delivered water charge: } \$ 359 / \mathrm{AF}\end{array}$ & $\mathrm{N} / \mathrm{A}$ \\
\hline Republican River Basin & $\begin{array}{l}\text { Corn, wheat, } \\
\text { soybeans }\end{array}$ & Varies by district & Varies by district & Varies by district \\
\hline $\begin{array}{l}\text { Santa Clara Valley Water } \\
\text { District }\end{array}$ & $\begin{array}{l}\text { Nursery crops, } \\
\text { mushrooms, wine } \\
\text { grapes }\end{array}$ & Included in water fee & $\begin{array}{l}\text { Zone W:2 } \\
\text { agricultural use: } \$ 21.36 / \mathrm{AF} \\
\text { nonagricultural use: } \$ 894 / \mathrm{AF} \\
\text { Zone W:5 } \\
\text { agricultural use: } \$ 21.36 / \mathrm{AF} \\
\text { nonagricultural use: } \$ 356 / \mathrm{AF}\end{array}$ & $\mathrm{N} / \mathrm{A}$ \\
\hline $\begin{array}{l}\text { Twin Platte Natural } \\
\text { Resources District }\end{array}$ & $\begin{array}{l}\text { Alfalfa, beans, corn, } \\
\text { wheat }\end{array}$ & Included in water fee & Levy taxes up to $\$ 100 /$ acre & $\mathrm{N} / \mathrm{A}$ \\
\hline $\begin{array}{l}\text { United Water } \\
\text { Conservation District }\end{array}$ & $\begin{array}{l}\text { Alfalfa, pasture, } \\
\text { orchards }\end{array}$ & Included in water fee & $\$ 40-\$ 150 / A F$ & $\mathrm{~N} / \mathrm{A}$ \\
\hline Upper Klamath Basin & $\begin{array}{l}\text { Cereal grains, } \\
\text { alfalfa, potatoes }\end{array}$ & Included in water fee & Operational fee: $\$ 66-\$ 100 / a c r e$ & $\mathrm{~N} / \mathrm{A}$ \\
\hline $\begin{array}{l}\text { Upper Republican Natural } \\
\text { Resources District }\end{array}$ & Cattle, grain, wheat & Levied in taxes & $\mathrm{N} / \mathrm{A}$ & $\mathrm{N} / \mathrm{A}$ \\
\hline Yakima Water District & $\begin{array}{l}\text { Hops, pears, } \\
\text { cherries }\end{array}$ & $\begin{array}{l}\text { New permit: } \\
\$ 50-\$ 25,000\end{array}$ & $\mathrm{~N} / \mathrm{A}$ & $\mathrm{N} / \mathrm{A}$ \\
\hline
\end{tabular}


over $\$ 14$ billion in value added to the regional economy. Note that value added is a measure of net economic activity and is consequently less than the gross value of production in these regions. Groundwater represents a significant share of the total water use that supports the industry. Rigid groundwater management approaches that significantly reduce irrigation water supply in these areas will result in significant and undesirable economic outcomes for these regions, violating a fundamental rule of sustainable groundwater management.

\section{Implementation of SGMA will substantially increase the value of recharged groundwater, and that value should be credited to the irrigator responsible. For example, growers of flood-irrigated alfalfa, which can generate substantial deep percolation without any nitrate leaching, should be allocated recharge credits.}

\section{Trading allocations}

Many basins limit trading of groundwater pumping allocations among users to prevent the concentration of pumping in one location. Excessive pumping in an area may cause a significant cone of depression, imposing additional costs on nearby wells, and potentially increasing subsidence or other environmental damage. Pfeiffer and Lin (2012), in their empirical analysis of groundwater spatial interdependencies in Kansas, found evidence of spatial externalities between local pumpers, where the cost of dropping groundwater levels caused by an individual is spread across many neighbors in the basin. Since an individual pumper gains all of the benefits of overdrafting but bears only a fraction of the cost, pumpers rationally overextract water compared to the optimal basinwide extraction rate. The sensitivity of a given groundwater basin to this effect is a function of several different hydrologic parameters.

Hydrologic considerations, however, are unlikely to dominate over the political and equity considerations of allowing trading among users. Orange County Water District, for instance, has good replenishment supplies and an effective, but unusual, groundwater management approach. There are no restrictions on groundwater pumping, however fees vary and are based on the current cost of replenishing the groundwater supply. Replenishment fees also differ spatially with discounts to surface water costs in regions near the coast. This provides an incentive to maintain the freshwater mound that prevents sea water intrusion that would degrade water quality in the basin.

\section{Carryover rights}

An important role of groundwater in California agriculture is to offset the hydrologic cycles of our Mediterranean climate and provide some stability in irrigation water supply during dry years. Allowing individual pumpers to carry over groundwater pumping rights between years is a natural way of providing this flexibility of water supply that is required for growing perennial crops in the California climate. However, 13 of the 18 districts surveyed did not allow any carryover of pumping rights between years, primarily to avoid excessive pumping in drought years. One district, the Twin Platte Natural Resources District, does not restrict carryover trades. The reason may be that this district has deployed an automated trading program that reduces trading costs and facilitates trades among willing farmers. Four districts allowed carryover for a limited number of years (usually 1 to 3 ). These short carryover periods may not work as a drought compensation mechanism in California. Major California droughts seem to occur about every seven years so a longer carryover period may be required to enable the use of groundwater as an effective drought reserve.

Initial studies show that in the San Joaquin Valley, current average annual overdraft represents between $0 \%$ and $24 \%$ of total water supplies, depending on location (Howitt et al. 2015). Clearly, the ability to recharge the existing groundwater basins is integral to the successful management of the basins.

\section{Incentivizing recharge credits}

In California, deep percolation from irrigated agriculture is an important part of the natural recharge of groundwater, and in some cases it equals or exceeds the natural recharge from other precipitation and subsurface flows. In many cases, then, a successful GSP will need to incentivize optimal recharge, whether it occurs from artificial spreading ponds or from deep percolation as a byproduct of existing irrigated agriculture.

The need to maintain a distributed source of recharge from irrigated agriculture may result in reassessing the concept of irrigation efficiency. Irrigation efficiency is measured as the ratio of water evapotranspired by the plant to the applied irrigation water. This definition ignores the value of deep percolated water and encourages its reduction. Ward and PulidoVelazquez (2008) and Qureshi et al. (2010) have analyzed the negative effects of water conservation on the amount of water available downstream in the Rio Grande and in Australia's Murray-Darling Basin, respectively.

Implementation of SGMA will substantially increase the value of recharged groundwater, and that added value should be credited to the irrigator responsible. For example, growers of flood-irrigated alfalfa, which can generate substantial deep percolation without any nitrate leaching, should be allocated recharge credits. Rather than being stigmatized as inefficient irrigation, flood irrigation could be credited as an efficient source of recharge.

In addition, water banking systems for the intentional recharge of imported surface water are not part 
of the natural hydrology of the basin, and therefore should not be included in the sustainable yield calculations or the annual allocations. In some locations, the natural recharge is practically nil due to soils and geology (e.g., in confined aquifers where horizontal flow is the dominant source of extractable groundwater). GSAs in such areas would need to partner with GSAs with recharge credits. For the GSAs with credits, some of their water would be assigned to meet their portion of annual natural recharge and any excess, net of losses, would become transferable to other GSAs on an annual basis. The accounting and management systems required would be complex.

In our survey of 18 districts, we found no formal requirements for measuring an individual user's contribution to recharge and no examples of incentives for an individual user to increase or maintain high levels of recharge to the groundwater basin. We envisage that effective recharge incentives for individual users would be provided by a system of net metering of groundwater use similar to the system that incentivizes individual solar energy generation. Using information on irrigation technology and crops grown, recharge credits could be calculated as part of net metering. The GSA would maintain for each user a groundwater escrow account that considered both withdrawals from and contributions to the groundwater basin.

\section{Our conclusions, what applies in California}

The most contentious decision for each GSA contemplating a GSP is likely to be the method used to allocate the basin sustainable yield among members. Phase-in periods will be important, but in the long-run a correlative rights approach that allocates water share by overlying land area seems to be the most equitable.
The second conclusion we draw from the survey is that pumping must be metered - either directly with meters and crop coefficients, or indirectly through remote sensing - for effective groundwater management. It is not possible to manage groundwater without knowing how much is used.

The third conclusion focuses on the important role groundwater plays in California in balancing inherently variable surface water supplies. Due to climate and crop differences, it follows that groundwater management rules in California should have more flexibility over both time and space than the rules adopted by most established Western water systems. Finally, because of the importance of deep percolation from crops as a source of groundwater recharge, we need a management system that will incentivize recharge on a distributed basis.

Given the common property nature of groundwater, where the costs of an individual's overpumping are spread across all pumpers in the basin, it is natural to find that unmanaged basins are overexploited. Since the primary goal of groundwater management is to end this overexploitation and stabilize the average depth of each basin, assessing how groundwater management has been addressed in other regions will provide a background of approaches that can help GSAs form their GSPs. CA

C. Newman is Senior Credit Analyst, CoBank, Rocklin, CA; R. Howitt is Principal at ERA Economics and Professor Emeritus, Agricultural and Resource Economics, UC Davis; and D. MacEwan is Principal, ERA Economics, Davis, CA.

\section{References}

Allen RG, Tasumi M, Morse A, Trezza R. 2005. A Landsat-based energy balance and evapotranspiration model in Western US water rights regulation and planning. Irrig Drain Syst 19(3-4):251-68.

Austin C. 2014. Reactions: Legislators and organizations respond to the passage of groundwater legislation. August 30, 2014. Maven's Notebook. http://mavensnotebook com/2014/08/30/reactionslegislators-and-organizationsrespond-to-the-passage-ofgroundwater-legislation/.

Bostock RM, Pye MF, Roubtsova TV. 2014. Predisposition in plant disease: Exploiting the nexus in abiotic and biotic stress perception and response. Annu Rev

Phytopathol 52:517-49.
Browne GT, Micretich M. 1988. Effects of flood duration on the development of Phytophthora and crown rots of apples. Phytopathology 78(6):846-51.

[DWR] California Department of Water Resources. 2016a. Groundwater Information Center. Key legislation. www.water ca.gov/groundwater/groundwater_management/legislation. cfm (accessed July 15, 2016).

DWR. 2016b. California Statewide Groundwater Elevation Monitoring (CASGEM). www. water.ca.gov/groundwater/casgem/overview.cfm (accessed Nov. 10, 2016).

Howitt RE, MacEwan DM, Medellín-Azuara J, et al. 2015. Economic Analysis of the 2015 Drought for California Agriculture. Center for Watershed Sciences, University of California, Davis. $31 \mathrm{p}$.
Nelson D. 2015. Flooding farms in the winter may help replenish groundwater. UC Davis News \& Information. www. ucdavis.edu/news/floodingfarms-winter-may-help-replenish-groundwater/ (accessed April 10, 2017)

O'Geen AT, Saal M, Dahlke $\mathrm{H}$, et al. 2015. Soil suitability index identifies potential areas for groundwater banking on agricultural lands. Calif Agr 69(2):75-84. https://doi. org/10.3733/ca.v069n02p75 (accessed April 10, 2017).

Pfeiffer L, Lin C-YC. 2012. Groundwater pumping and spatial externalities in agriculture. J Environ Econ Manag 64(1):16-30.
Qureshi MEM, Whittem A, Kirby M. 2010. A multi-period positive mathematical programming ap proach for assessing economic impact of drought in the Murray Darling Basin, Australia. 56th AARES Annual Conference, Feb. 7-11, 2012. Fremantle, WA

[SWRCB] California State Water Resources Control Board. 2012. Evaluation of San Joaquin River Flow and Southern Delta Water Quality Objectives and Implementation. Appendix F.2. In: Substitute Environmental Document in Support of Potential Changes to the Water Quality Control Plan for the San Francisco Bay-Sacramento/San Joaquin Delta Estuary: San Joaquin River Flows and Southern Delta Water Quality. December 2012. ICF 00427.11.
Theesfeld I. 2011. Perceived power resources in situations of collective action. Water Altern 4(1): 86-103.

Ward F, Pulido-Velazquez M. 2008. Water conservation in irrigation can increase water use. P Natl Acad Sci USA105(47):18215-20.

Wildermuth Environmental. 2013. 2013 Chino Basin Groundwater Model Update and Analysis of Safe yield. www.cbwm. org/FTP/Safe\%20Yield\%20 Reset/20130829\%20Workshop $\% 20 \% 232 / 20130829 \% 20$ Safe\%20Yield\%20Recalculation\%20Workshop\%20No.\%20 2\%20Presentation\%20(WEI).pdf (accessed April 3, 2016). Lake Forest, CA: Wildermuth Environmental, Inc. 74 p. 